\title{
Can a South East European Country Have a Strong Currency? Albania Case
}

\section{Summary}

The dilemma which is presented in this article is connected with problem of excessive for a currency. The discussion is based on South Eastern European country case, which is the Albania and its currency - Lek. This currency has a very low marketability outside Albania and a pretty short history in the currency exchange market, during which it had experienced high fluctuations. But we should accept that after the 2000 's, our national currency began to reach relatively constant ratios with the main currencies on the exchange market. This stability has fulfilled the normalization picture of the macroeconomic parameters, which were so much unstable during the fast essential changes that happened in the first years of transition.

In this article we will try to present the real position of the Albanian currency in the Albanian exchange market.

\section{Introduction}

Nowadays the debate regarding the impact of the exchange rate on the economic performance has reached new levels. In the past the attention was focused on the impact of the exchange rate regime on the economic growth, inflation, and the financial system as a whole. Actually the emphasis is more and more on a deeper problem.

The majority of the developing countries, like Albania, suffer form the "sin" of having a currency with which they cannot buy abroad and which is used a little or not at all in the long term lending contracts, even for those signed within the country. Because of this

\footnotetext{
${ }^{*}$ Faculty of Economy, Tirana University, Albania.

${ }^{* *}$ Faculty of Economy, Tirana University, Albania.
} 
the financial system of these countries is relatively weak since the local investments, will have a discrepancy of the currency with which they are done, or will a have a maturity discrepancy. This brings out that regardless of the exchange rate regime, fixed or flexible, it will be a problem again. This means that the only solution, according to many studiers, is to eliminate the exchange rate. In other words, the developing countries should abandon their weak currency and implement in the economy one of the strong currencies like the American dollar, the Euro etc.

In this context some questions are naturally generated:

- Why do the developing countries usually have a weak currency?

- Does exist any way for these countries to have a stronger currency in order that the eurozation or dollarization cannot be the only way to have a healthy financial system?

- Can Albania have a proper strong currency? Has the Albanian Lek been strong ever?

\section{What makes a currency strong?}

There are existed at least two different definitions of a strong currency. According to one of them, a strong currency is widely used for the international transactions and as a value reserve. It means that only few world currencies have these functions. It is Yen, USD, Euro, and some other European currencies.

According to a broader definition, a currency is called strong when it is widely used in the long term lending contracts, by making possible the development of the long term financial market. This definition assesses a currency to be strong based on the benefits that it brings to the economy. And naturally, there are a big number of currencies and countries which can be included according to the second definition, which is wider in comparison to the first definition of the strong currency. However we can say that according to this definition, we cannot call the currencies of the developing countries are strong or strong enough.

According to both definitions presented above, the strong currency is a part of the same process, during which the long term financial market is firstly dominated by the national currency, and further, if the region and the world have very few strong currencies, they are widely used in the international transactions. So someway "the strong currency service" can be exported from a certain country to the other countries of the region.

\section{The Albanian Lek - relatively constant or strong?}

To determine how our national currency is strong or weak is a little bit difficult. In appearance it may seem easy to determine a currency value since it does exist a market price on which can be risen judgments. But we should be aware that the markets are never perfect.

Sometimes the exchange rates can be noticed if they are high or low. Much often it can be noticed even rather intuitive than from the numerical results of the foreign 
exchange markets. So for example if the imported products seem to have lower prices than they usually do than can be noticed that the Albanian currency is relatively strong in comparison to the currencies of the countries where the imports come from and vice versa. Regardless of this, to receive an argued answer if the Albanian Lek is or not a strong currency it is necessary to analyze the main factors that have affected its value during the last years.

\subsection{The Lek value trend during the years 2000s}

In general it is accepted that during the last years the Albanian Lek has been relatively stable in relation to the main currencies in the world like the dollar, euro, pound etc. Even based on the statistical data we can say that this stability is accompanied with a strengthening of the national currency during this period.

Table 1. The exchange rate (ALL/EU, ALL/USD)

\begin{tabular}{|l|c|c|c|c|c|c|c|c|c|c|}
\hline E.R./Year & $\mathbf{1 9 9 9}$ & $\mathbf{2 0 0 0}$ & $\mathbf{2 0 0 1}$ & $\mathbf{2 0 0 2}$ & $\mathbf{2 0 0 3}$ & $\mathbf{2 0 0 4}$ & $\mathbf{2 0 0 5}$ & $\mathbf{2 0 0 6}$ & $\mathbf{2 0 0 7}$ & $\mathbf{2 0 0 8}$ \\
\hline ALL/USD & 137.69 & 143.71 & 143.53 & 140.15 & 121.86 & 102.78 & 99.87 & 98.10 & 90.43 & 85.01 \\
\hline ALL/EURO & 146.96 & 132.58 & 129.04 & 132.36 & 137.51 & 127.67 & 124.19 & 123.08 & 123.62 & 122.88 \\
\hline
\end{tabular}

Source: Bank of Albania.

Based on the official data of the Bank of Albania, we can say that the fluctuations of the exchange rates of the Lek during the years 2000s have been gradual and balanced. This stability trend accompanied with an over pricing of the national currency continued during all this period. At the end of 2007 our national currency was over priced as an average nearly $51 \%$ against the USD and $19 \%$ against the Euro, in comparison to 1999 . The ongoing over pricing of the Lek, mostly reflect the positive trend of the balance of payments, especially the considerable inflows in foreign currency. The emphasized over pricing of the Lek against the dollar mostly is influenced by the fall of the USD value in the international markets. While the exchange of Lek with Euro is mostly affected by internal factors, since Euro is the main currency of the foreign trade and it is used in a big part of the transactions in the local market. Finally we can say that the Lek over pricing was slowed during the last two years. 


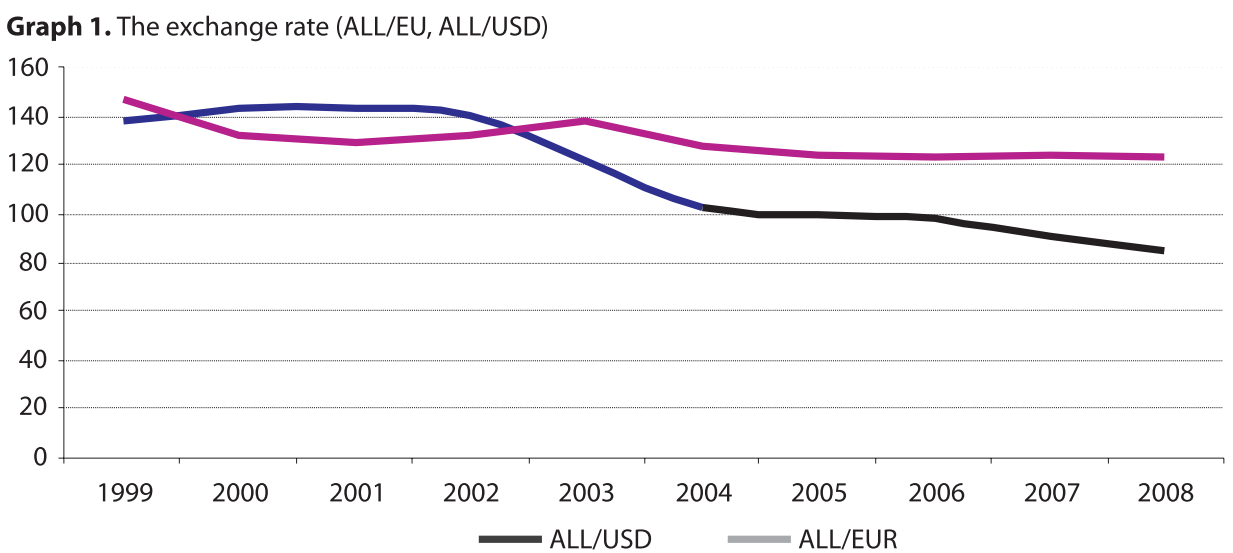

Source: Bank of Albania.

\subsection{The factors that influenced the Lek value during the years $2000 \mathrm{~s}$}

In the exchange rate of the national currency with the main currencies of the market, during the years 2000s influenced many factors and as the most determinants from them we can distinguish:

a) The development in the international foreign currency markets especially the big fall of the American dollar value during the period 2003-2007. The fast and the equitable transmission of this depreciation is a sign of the high interaction that exist between the local market and the international foreign currency markets.

b) The positive difference of the interest rates offered by the investments in Lek in comparison to those in foreign currency. Actually the interest rates in Lek continue to have differences with the interest rates in foreign currency. Even after the last financial crisis, the trend of the falling interest rates for the dollar (LIBOR) and the Euro (EURIBOR) from one side, and the trend of the interest rates growing for the loans in Lek noticed in some banks, from the other side, increase this difference making further pressure in the national currency strengthening. More precisely, during the last years LIBOR level has been mostly lower than the EURIBOR, which has been lower than the base interest rate in Albania that is the rate of the REPO. According to the statistics, the base interest rate for the loan in Lek (REPO) had a falling trend until the 2005 when it reached its lowest historical level about 5,00\%. After this year the base interest rate has been increasing five times with 0,25 percentage points reaching the actual level of $6,25 \%$. The table 2 shows data about the base interest rates of the national currency (Lek) and the two main currencies in the international markets, Euro and USD.

The fluctuation of the interest rate during this 5 years period happened because of the politics of the Bank of Albania to facilitate the lending in a developing economy like Albania is and also kept a harmony with the fluctuations of the LIBOR and EURIBOR interest rates. Graph 2 have presented the trend of the weakly REPO rate and the weakly EURIBOR during the last 5 years. 
Table 2. Interest rates of EURIBOR, LIBOR and REPO during the last 5 years

\begin{tabular}{|l|c|c|c|c|c|}
\hline \multirow{2}{*}{ Currency/Year } & \multirow{2}{*}{ REPO } & \multirow{2}{*}{ EURIBOR } & \multirow{2}{*}{ LIBOR } & \multicolumn{2}{|c|}{ Differences } \\
\cline { 5 - 6 } & & & & REPO-EURIBOR & REPO-LIBOR \\
\hline 1-Jan-03 & $8.50 \%$ & $2.91 \%$ & $1.35 \%$ & $5.59 \%$ & $7.15 \%$ \\
\hline $30-$ Apr-03 & $8.00 \%$ & $2.58 \%$ & $1.32 \%$ & $5.42 \%$ & $6.68 \%$ \\
\hline 16-Jul-03 & $7.50 \%$ & $2.12 \%$ & $1.10 \%$ & $5.38 \%$ & $6.40 \%$ \\
\hline 5-Nov-03 & $7.00 \%$ & $2.07 \%$ & $1.09 \%$ & $4.93 \%$ & $5.92 \%$ \\
\hline 30-Dec-03 & $6.50 \%$ & $2.25 \%$ & $1.09 \%$ & $4.26 \%$ & $5.41 \%$ \\
\hline 29-Apr-04 & $6.25 \%$ & $2.06 \%$ & $1.08 \%$ & $4.19 \%$ & $5.17 \%$ \\
\hline 12-May-04 & $6.00 \%$ & $2.05 \%$ & $1.08 \%$ & $3.95 \%$ & $4.92 \%$ \\
\hline 24-Jun-04 & $5.75 \%$ & $2.08 \%$ & $1.34 \%$ & $3.67 \%$ & $4.42 \%$ \\
\hline 28-Jul-04 & $5.50 \%$ & $2.08 \%$ & $1.34 \%$ & $3.42 \%$ & $4.17 \%$ \\
\hline 4-Nov-04 & $5.25 \%$ & $2.12 \%$ & $1.99 \%$ & $3.13 \%$ & $3.26 \%$ \\
\hline 31-Mar-05 & $5.00 \%$ & $2.10 \%$ & $2.85 \%$ & $2.90 \%$ & $2.16 \%$ \\
\hline 12-Jul-06 & $5.25 \%$ & $2.85 \%$ & $5.31 \%$ & $2.40 \%$ & $-0.06 \%$ \\
\hline $30-N o v-06$ & $5.50 \%$ & $3.34 \%$ & $5.30 \%$ & $2.16 \%$ & $0.20 \%$ \\
\hline $28-J u n-07$ & $5.75 \%$ & $4.09 \%$ & $5.32 \%$ & $1.67 \%$ & $0.43 \%$ \\
\hline 27-Sep-07 & $6.00 \%$ & $4.22 \%$ & $5.07 \%$ & $1.78 \%$ & $0.93 \%$ \\
\hline $30-N o v-07$ & $6.25 \%$ & $4.11 \%$ & $4.87 \%$ & $2.14 \%$ & $1.38 \%$ \\
\hline $30 / 11 / 2008$ & $6.25 \%$ & $3.18 \%$ & $1.04 \%$ & $3.07 \%$ & $5.21 \%$ \\
\hline
\end{tabular}

Graph 2. Interest rates of EURIBOR, LIBOR and REPO during the last 5 years

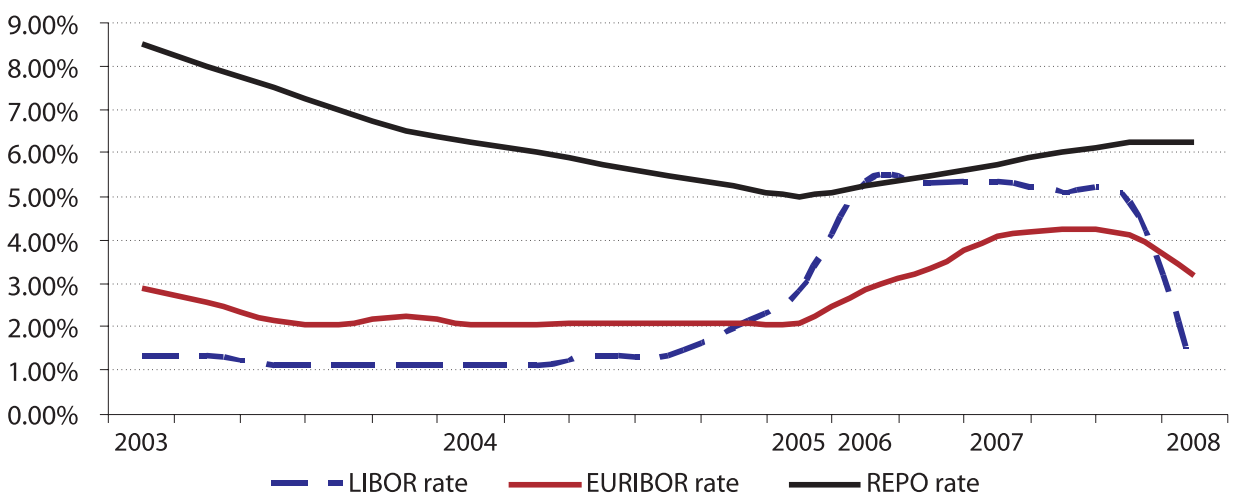

It is obvious that the base interest rate for the loan in Lek kept a positive difference with the interest rates for the loan in dollars and euro. An exception is the period July November 2006 when LIBOR has been higher than the REPO and this was conditioned by the fast and considerable growing of the interest rate for the dollar that happened because of the fall in the American currency value and the situations in the lending markets in USA. The difference between the REPO rate and the EURIBOR and LIBOR 
Graph 3. Differences in interest rates between REPO, LIBOR and EURIBOR, during the last 5 years

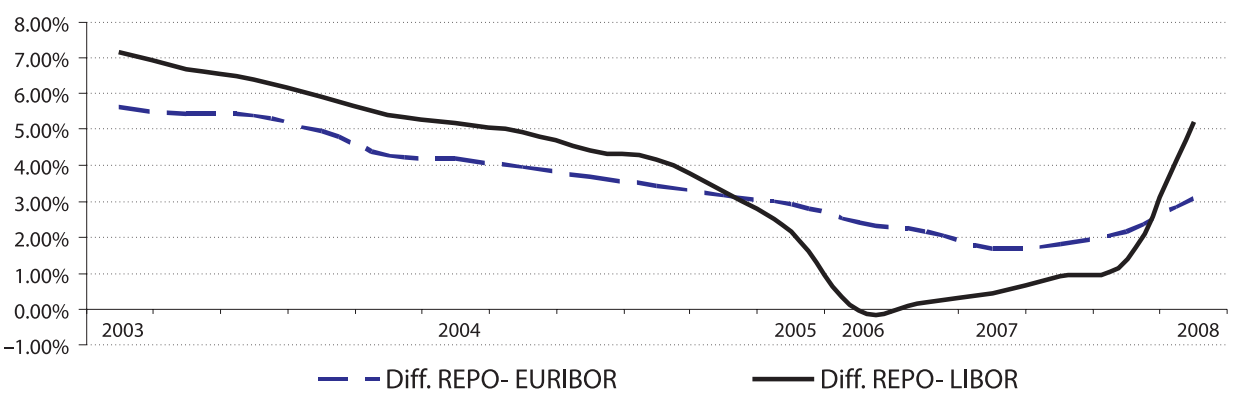

interest rates has been high in the first years. This difference has been decreasing during the next years and has an increasing trend during this year.

c) The process of the physic appearance of the European common currency (Euro) influenced during the years 2000 and 2001 in the supply growth of the European national currencies which would be replaced by the Euro, such as the Greek drachma, lire, mark, French franc, etc. This grown supply over priced the Albanian Lek during this period.

d) The period 2000-2007 can be said to be characterized from the achievement and the keeping of the monetary and fiscal parameters according to the aimed levels (Bank of Albania). This macroeconomic stability had its influence and is complemented by the stability of the foreign exchange market.

e) The high levels of remittances were not only in the first years of the transition but during the years 2000s too, and have influenced in the foreign currency supply growth, especially for Euro, and the demand growth for Albanian Lek. These remittances also have been the cause of the seasonal fluctuations of the foreign currency market because of the seasonal nature that they had. Usually during April, July, August and December there are noticed increases in remittances and in the same time the over pricing of the Albanian Lek followed by a depreciation of it in the following periods.

f) It is to be emphasized that the exchange rate kept its stability uninfluenced by the political events like the political elections which in the past had their influence in its trend. This demonstrates for a stability growth in the market, mainly caused by the competition growth, the activity growth, and a responsible politics in the monetary and fiscal sphere during this period.

g) Factors with an important influence in the national currency value have been also the events happened in the financial market in general. So, for example, the difficult situation regarding liquidity in the banking system in the first half of the year 2002, coincided with a delicate moment in the relations between demand and supply for foreign currency in the local foreign exchange market. The deposits withdrawal, mainly in Lek, in part of the second level banks increased further the liquidity out of the system, which appeared high as a result of the increased supply (sales) of the foreign currencies (DEM, ITL and GRD) components of the Euro, in the period at the end of 2001 and the beginning of the 2002, when the replacement of those with Euro happened. The combined effect of 
these developments caused a fast under pricing of the Lek during some months like March, April and May of that year (Bank of Albania, Annual Report, 2002).

h) The imports growth during all the transition period has been a factor that supported the demand for foreign currency influencing in the Albanian Lek under pricing. But the slow growth in the exports and especially the foreign currency supply brought by the remittances inflows and the foreign direct investments have equilibrated this under pricing pressure, giving so as a result the value stability keeping of the Albanian Lek.

i) The economic theory and experience show that the currencies with a low inflation have the trend to strengthen against the currencies with high inflation rates. In the last seven years, the inflation rates differences of our currency against the dollar and the euro have been in an interval zone around to zero.

j) The high rates of the economic growth are accompanied with a strengthening of the currency at the same size that this growth improves the competitive position of the country. During this period, the Albanian economy experienced high and constant growth rates, in an environment with low inflation rates.

Table 3. The foreign trade balance (in million Euro)

\begin{tabular}{|l|c|c|c|c|c|c|c|c|}
\hline \multicolumn{1}{|c|}{ Year } & $\mathbf{2 0 0 0}$ & $\mathbf{2 0 0 1}$ & $\mathbf{2 0 0 2}$ & $\mathbf{2 0 0 3}$ & $\mathbf{2 0 0 4}$ & $\mathbf{2 0 0 5}$ & $\mathbf{2 0 0 6}$ & $\mathbf{2 0 0 7}$ \\
\hline Imports & 1.07 & 1.39 & 1.7 & 1.75 & 1.83 & 2.08 & 2.41 & 3.04 \\
\hline Exports & 0.25 & 0.31 & 0.37 & 0.42 & 0.48 & 0.53 & 0.63 & 0.78 \\
\hline The trade volume & 1.32 & 1.7 & 2.07 & 2.17 & 2.31 & 2.61 & 3.04 & 3.82 \\
\hline The trade deficit & 0.82 & 1.08 & 1.33 & 1.33 & 1.35 & 1.55 & 1.78 & 2.26 \\
\hline
\end{tabular}

Source: Bank of Albania.

Table 4. GDP (in billion ALL)

\begin{tabular}{|l|c|c|c|c|c|c|c|c|c|c|c|c|c|}
\hline \multicolumn{1}{|c|}{ The Indicator } & $\mathbf{1 9 9 6}$ & $\mathbf{1 9 9 7}$ & $\mathbf{1 9 9 8}$ & $\mathbf{1 9 9 9}$ & $\mathbf{2 0 0 0}$ & $\mathbf{2 0 0 1}$ & $\mathbf{2 0 0 2}$ & $\mathbf{2 0 0 3}$ & $\mathbf{2 0 0 4}$ & $\mathbf{2 0 0 5}$ & $\mathbf{2 0 0 6}$ & $\mathbf{2 0 0 7}$ & $\mathbf{2 0 0 8}$ \\
\hline GDP at current prices & 346,403 & 346,198 & 409,209 & 471,578 & 523,043 & 583,369 & 622,711 & 694,098 & 750,785 & 814,797 & 891,000 & 940,005 & $1,033,065$ \\
\hline $\begin{array}{l}\text { The annual real } \\
\text { growth of GDP, (in \%) }\end{array}$ & 9 & -11 & 9 & 14 & 7 & 8 & 4 & 6 & 6 & 6 & 6 & 5.5 & $9.9^{1}$ \\
\hline
\end{tabular}

Source: Bank of Albania.

${ }^{1}$ INSTAT. There is a debate between INSTAT, Government and IMF about the real GDP growth for 2008.

Graph 4. GDP Growth (in percentage)

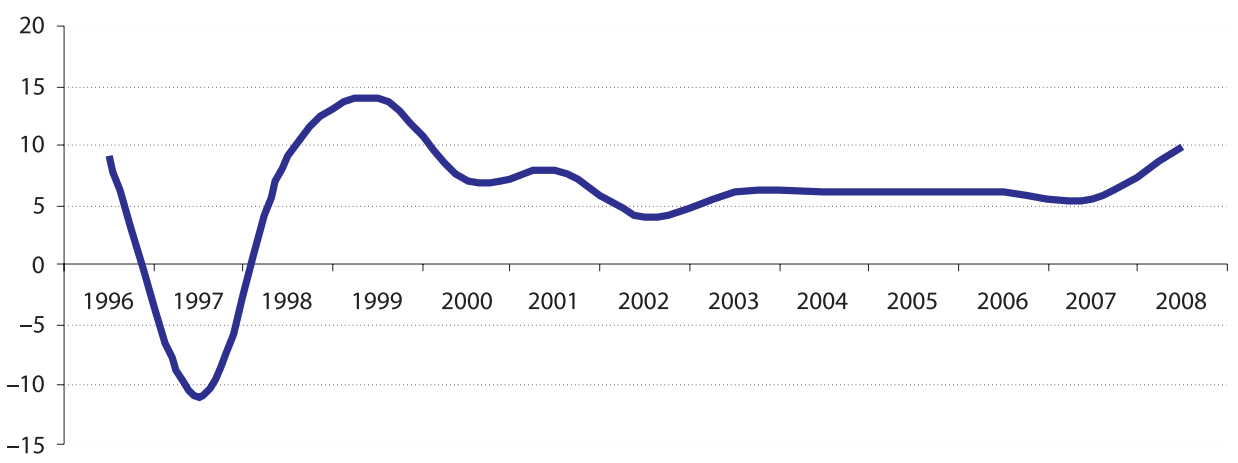


k) The Bank of Albania interventions in the foreign currency market have been a factor that mostly had the aim to soft the seasonal fluctuations that came form the inflows in foreign currency. Usually the interventions were focused in the foreign currency buying from the second level banks.

\section{Is the Albanian currency a strong one or not?}

If we would refer to the trend of the Lek exchange rate with the main currencies, Euro and dollar, it is clear that Albanian currency has followed an over pricing trend without high fluctuations. So we can say that during this period we had a stable currency and with a growing value. The currency which has achieved to resist to the events like the political elections have caused "earthquakes" in the Lek value. A foreign currency market has transmitted fast and precisely the development in the international markets. Higher interest rates than the LIBOR and the EURIBOR a factor which influenced the Albanian Lek strengthening. Stable macroeconomic parameters and an economy with a stabilized growth, high imports but also high foreign currency inflows mainly by remittances, a financial market generally under control and a Central Bank which has intervened from time to time are benefiting the market stabilization. But are this enough to say if the Albanian Lek is a strong currency or not?

At the beginning of this paper we presented two definitions regarding a strong currency. What we know for sure is that the Albanian Lek is not widely used in the international transactions and also it is not used as a value stock except in Albania. So according to the first definition it cannot be said that we have a strong currency since this status belongs only to some main currencies in the world.

To have an answer we should analyze how much it is used our currency in the long term lending contracts.

Actually the lending market in Albania is composed by the treasury bills, the treasury bonds, and the banking loans markets. The midterm lending market is composed only by the banking loans and the treasury bonds. The midterm and long term banking loans are dominated by the loans for equipments and the mortgage loans. At the beginning of the years 2000s when it started to boom the loan market in Albania these loan contracts have been dominated by the loans in foreign currency mainly USD, lire and drachma (later Euro) because the banks did not feel secure with the Albanian Lek value (statistics). In the last years, when the Lek started to show stability, then the banks started to use it for the lending. Today it can be said that the biggest part of the loans are given in Lek and our national currency is dominating in the long term lending contracts in Albania and is really influencing in the financial market health and development in the sizes that this market actually have.

As it can be seen from the graph the weight of the loan stock has been growing with the passing of years. A characteristic is the growing of the loan stock in foreign currency. This growth reached the record level in 2003 when the foreign currency loans stock composed $82 \%$ of the total loans. This high level of lending in foreign currency until this moment clearly exposed the banking system to the foreign exchange risk. This increased 
Table 5. The loan to the economy (in million Lek)

\begin{tabular}{|l|r|r|r|r|r|r|r|r|}
\hline \multicolumn{1}{|c|}{ Year } & $\mathbf{2 0 0 0}$ & $\mathbf{2 0 0 1}$ & $\mathbf{2 0 0 2}$ & $\mathbf{2 0 0 3}$ & $\mathbf{2 0 0 4}$ & $\mathbf{2 0 0 5}$ & $\mathbf{2 0 0 6}$ & $\mathbf{2 0 0 7}$ \\
\hline Total loans & 23.2 & 27.9 & 38.6 & 50.6 & 69.9 & 121.9 & 191.2 & 287.5 \\
\hline In ALL & 8.4 & 5.1 & 8.1 & 9.1 & 13.6 & 31.0 & 55.3 & 79.7 \\
\hline In ALL (\%) & 36.2 & 18.2 & 20.9 & 17.9 & 19.4 & 25.4 & 28.9 & 27.7 \\
\hline In foreign currency & 14.8 & 22.8 & 30.5 & 41.5 & 56.3 & 90.9 & 135.9 & 207.8 \\
\hline In foreign currency (\%) & 63.7 & 81.7 & 79.0 & 82.0 & 80.5 & 74.5 & 71.0 & 72.2 \\
\hline
\end{tabular}

Graph 5. The trend of the ratio In ALL loans / total loans

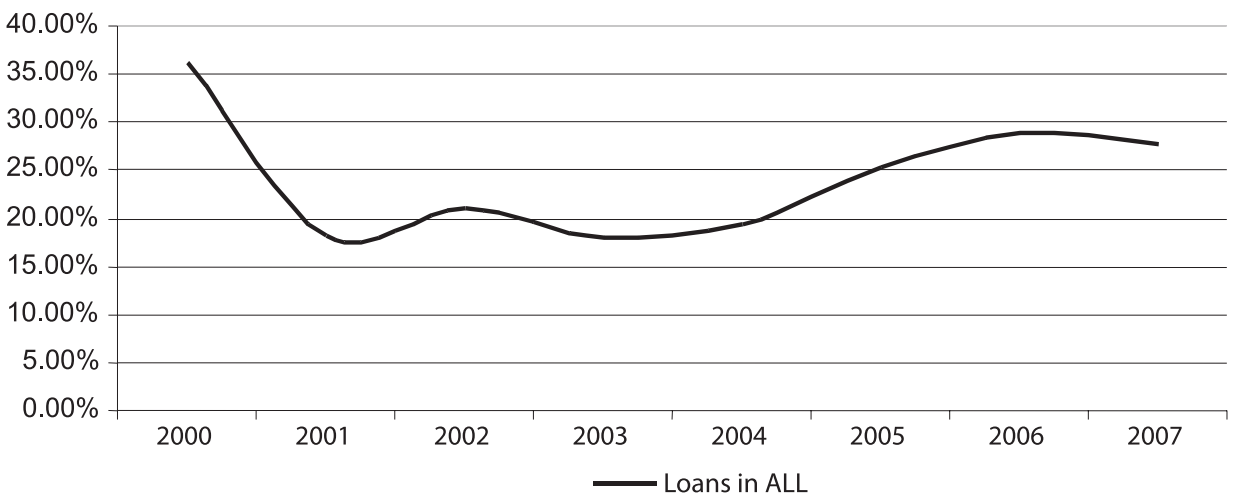

exposure and also the just appeared stability of the Lek in those years created the sufficient trust in the banking system to increase the level of lending in the national currency. This growth year by year increased constantly the loans stock in the national currency which until the end of 2007 was at $27,7 \%$ of the loans stock. Naturally there will be years until the loans in Lek stock will be dominating because actually in the total loan stock a considerable part of the loans is composed by the loans in foreign currency given during the years 2000-2003.

\section{Conclusions}

The Lek is not yet dominating in the long term lending contracts. What has happened these years are signs of the strengthening of our national currency and its attempt to have the place it deserves in the development of the Albanian financial system. It is because of the short period of time with macroeconomic stability (seven years) and with foreign exchange market stability that it was not sufficient to place the Albanian Lek in the position it deserves in the economy. This is one of the reasons that the foreign currencies, mainly Euro and USD, are still active in the purchasing and selling transactions and in the long term lending contracts.

We feel as necessary to emphasize that with this work our aim was not to find arguments in favor of the strength of the Albanian Lek or to give nationalists thesis for 
the keeping of the national currency. This means that even we asses that our national currency for some years achieved to do well its "job", we are aware that the future of Albania toward the EU will replace the Lek with the European currency. We believe that this replacement will influence positively not only in the Albanian financial system health but in the economy as a whole.

\section{References}

Bank of Albania (2000), Annual Report

Bank of Albania (2001), Annual Report

Bank of Albania (2002), Annual Report.

Bank of Albania (2003), Annual Report.

Bank of Albania (2004), Annual Report.

Bank of Albania (2005), Annual Report.

Bank of Albania (2006), Annual Report.

Bank of Albania (2007), Annual Report.

Bank of Albania (2008), Periodical Reports during 2008 Ministry of Finance INSTAT - Institute of

Statistics.

Bank of Albania, Time series.

Goldfajn I., Rigobon R., Hard Currency and Financial Development

Schnabl G., Weak Economy and Strong Currency - the Origins of the Strong Yen in the 1990 's.

\section{Czy państwa Europy Południowo-Wschodniej mogą mieć silne waluty? Przypadek Albanii}

\section{Streszczenie}

$W$ artykule poruszony zostat ciekawy problem badania sity ekonomicznej walut narodowych $w$ warunkach powszechnego postugiwania się na rynku walutami globalnymi. Rozpatrywane zagadnienie oparto na analizie wartości i znaczenia waluty albańskiej, czyli leka. Autorzy, na podstawie analizy waluty albańskiej, zadali sobie pytanie, czy waluty krajowe moga być we współczesnym świecie walutami silnymi. Jeśli nie, to czy jest sens posiadania przez dany kraj własnej waluty, czy z punktu widzenia ekonomicznego nie byłoby wskazanym oparcie gospodarki na sile walut międzynarodowych. Rozważania teoretyczne uzupetnione zostały licznymi danymi pochodzacymi z Narodowego Banku Albanii. 